\title{
HUBUNGAN KEBIASAAN MAKAN DAN ASAP ROKOK TERHADAP HASIL PEMERIKSAAN IVA (INSPEKSI VISUAL ASETAT) DI KABUPATEN PEKALONGAN
}

\author{
Relationship Of Food And Cigarette Habits On The Results Of Iva Examination \\ (Acetatic Visual Inspection) In Pekalongan District \\ Nina Zuhana ${ }^{1}$, Wahyu Ersila ${ }^{2}$,Rini Kristiyanti ${ }^{3}$ \\ STIKES Muhammadiyah Pekajangan Pekalongan \\ (ninazuhana@gmail.com)
}

\begin{abstract}
ABSTRAK
Latar Belakang : Kanker serviks atau kanker leher rahim merupakan salah satu kanker yang paling sering menyerang wanita menurut WHO menempati urutan kedua sebagai penyebab kematian terbanyak setelah penyakit kardiovaskuler. Penyebab kanker ini adalah infeksi dari Human papiloma Virus (HPV).Beberapa faktor risiko yang secara tidak langsung diduga berpengaruh terhadap pertumbuhan HPV sehingga terjadi lesi prakanker leher rahim meliputi status social ekonomi, factor aktivitas seksual, multiparitas, kurang menjaga kebersihan genital, merokok, riwayat kebiasaan makan makanan yang berlemak, riwayat penyakit kelamin serta penggunaan kontrasepsi oral dalam jangka waktu lebih dari 4 tahun

Tujuan : Penelitian ini bertujuan untuk mengetahui hubungan kebiasaan makan dan Asap rokok terhadap hasil pemeriksaan IVA di Kabupaten Pekalongan.

Metode : Penelitian ini menggunakan desain Deskriptif Korelatif dengan rancangancross sectional. Populasipenelitianini adalah seluruhwanita usia subur di wilayah Kabupaten Pekalongan. Subyek penelitian ini seluruh wanita di wilayah Kabupaten Pekalongan yang melakukan pemeriksaan IVA di STIKES Muhammadiyah Pekajanganpada tanggal 6 Maret 2018 yang berjumlah 206 orang. Pada penelitian ini menggunakan alat pengumpul data berupa kuesioner. Analisa data dalam penelitian ini menggunakan Uji Spearman rank.

Hasil : Sebagian besar 77,7\% wanita mempunyai kebiasaan makan dengan mengkonsumsi makanan berlemak dan berpengawet. Wanita yang terpapar asap rokok sebanyak 38,3\% dan terdapat sebagian kecil wanita $(4,9 \%)$ dengan hasil pemeriksaan IVA positif. Hasil korelasi dengan uji Spearman Rankdidapatkan0,340tidak ada hubungan yang signifikan antara kebiasaan makandengan hasil pemeriksaan IVA dan nilai signifikansi 0,150 yang berarti tidak ada hubungan antara asap rokok dengan hasil pemeriksaan IVA

Simpulan: Tidak ada hubungan antara kebiasaan makan dan asap rokok dengan hasil pemeriksaan IVA dg nilai $\mathrm{p}>0,05$
\end{abstract}

Kata kunci: Kebiasaan Makan, Asap Rokok, Hasil Pemeriksaan IVA

Hubungan Kebiasaan Makan Dan Asap Rokok Terhadap Hasil Pemeriksaan Iva (Inspeksi Visual Asetat) Di Kabupaten Pekalongan

(Nina Zuhana, Wahyu Ersila, Rini Kristiyanti) 


\begin{abstract}
Background:Cervical cancer or cervical cancer is one of the cancers that most often affects women according to WHO ranks second as the leading cause of death after cardiovascular disease. The cause of this cancer is an infection of Human Papilloma Virus (HPV). Some risk factors that are indirectly thought to influence the growth of HPV so that cervical precancerous lesions occur including socioeconomic status, factors of sexual activity, multiparity, lack of maintaining genital hygiene, smoking, a history of fatty eating habits, a history of venereal disease and oral contraceptive use within more than 4 years

The Purpose : This study aims to determine the relationship between eating habits and cigarette smoke on the results of IVA examination in Pekalongan Regency.

Method:This research uses descriptive correlative design with cross sectional design. The population of this study were all women of childbearing age in the Pekalongan Regency area. The subjects of this study were all women in the Pekalongan Regency area who conducted IVA examinations at the Muhammadiyah STIKES Pekajangan Pekalongan on March 6, 2018 totaling 206 people. In this study using a data collection tool in the form of a questionnaire. Data analysis in this study used Rank Spearman Test

Result:Most $77.7 \%$ of women have eating habits by consuming fatty foods and preservatives. Women who were exposed to cigarette smoke were $38.3 \%$ and there were a small percentage of women (4.9\%) with positive IVA results. The results of the correlation with the Rank Spearmantest were 0.340 with a significant number of 0.150 so there was no significant relationship between eating habits and cigarette smoke with the results of IVA examination

Conclusion:.There is no relationship between eating habits and cigarette smoke with the results of IVA examination with $p$ values $>0.05$
\end{abstract}

Keywords: Eating Habits, Cigarette Smoke, IVA Examination Results

\title{
PENDAHULUAN
}

Kanker serviks atau kanker leher rahim merupakan salah satu kanker yang paling sering menyerang wanita di seluruh dunia, bahkan menurut WHO, kanker serviks menempati urutan kedua sebagai penyebab kematian terbanyak setelah penyakit kardiovaskuler (Kemenkes RI, 2015). Kejadian kanker serviks atau kanker mulut rahim di Indonesia sangat tinggi.Sebuah data menyebutkan bahwa dalam satu tahun sekiranya terjadi 15.000 kasus kanker serviks.Dari 40 kasus wanita terdiagnosis kanker serviks, 20 diantaranya meninggal dunia (Handayani, dkk, 2012).

Kanker serviks ini disebabkan oleh infeksi dari Human papiloma Virus (HPV), biasanya terjadi pada perempuan usia subur. HPV ditularkan melalui hubungan seksual dan ditemukan 95\% kasus kanker serviks (Kumalasari, 2012).90\% dari kanker serviks berasal dari sel skuamosa yang melapisi serviks 
dan $10 \%$ sisanya berasal dari sel penghasil lendir pada saluran servikal yang menuju ke dalam rahim (Ranggiasanka, 2010).

Beberapa faktor risiko yang secara tidak langsung diduga berpengaruh terhadap pertumbuhan HPV sehingga terjadi lesi prakanker leher rahim meliputi status social ekonomi, factor aktivitas seksual, multiparitas, kurang menjaga kebersihan genital, merokok, riwayat kebiasaan makan makanan yang berlemak, riwayat penyakit kelamin serta penggunaan kontrasepsi oral dalam jangka waktu lebih dari 4 tahun (Diananda, 2009). Hasil Penelitian (Lestari 2016) tentang factor yang berhubungan dengan kejadian IVA positif menyatakan bahwa pendapatan perkapita, pendidikan, riwayat keluarga kanker, riwayat obesitas, konsumsi makanan yang berlemak, riwayat penyakit kelamin dan usia pertama kali menikah mempengaruhi kejadian IVA posistif.

Menurut Aris (2015) dari hasil penelitiaanya tentang kajian deteksi dini lesi prakanker leher rahim dengan metode IVA bahwa variabel yang berhubungan dengan dini lesi pra kanker leher rahim dengan menggunkan metode IVA adalah usia pertama kali menikah, merokok dan jumlah pasangan nikah sedangkan variabel yang tidak berhubungan adalah obesitas, penggunaan antiseptic, konsumsi makanan berlemak dan pendapatan..

Hasil penelitian Novya Dewi,dkk (2012) bahwa proporsi kasus lesi prakanker leher rahim terjadi pada responden dengan paparan asap rokok $(70,4 \%)$ dan paparan asap rokok dapat meningkatkan terjadinya lesi prakanker leher rahim sebesar 4,8 kali dibandingkan tidak terkena paparan asap rokok. Kandungan nikotin dalam asap rokok masuk dalam lender yang menutupi leher rahim sehingga menurunkan ketahanan alami sel leher rahim terhadap perubahan abnormal.

Salah satu metode skrining untuk mendeteksi prakanker adalah dengan pemeriksaan IVA, Pemeriksaan IVA (Inspeksi Visual dengan Asam Asetat) adalah pemeriksaan leher rahim secara visual menggunakan asam cuka (asam asetat) dengan mata telanjang untuk mendeteksi abnormalitas setelah pengolesan asam cuka 3-5\% (Kemenkes RI, 2015).

Berdasarkan data Dinas kesehatan provinsi Jawa Tengah, jumlah kasus kanker serviks menunjukkan angka yang cukup tinggi dan meningkat setiap tahunnya. Proporsi penyakit kanker serviks meningkat dari tahun 2013 sebesar 2.295 kasus $(25,10 \%)$ pada tahun 2014 menjadi 2.350 kasus $(31.23 \%)$ di kabupaten Pekalongan pada tahun 2014 dengan jumlah wanita yang melakukan pemeriksaan IVA sebanyak 1.213wanita dan yang IVA posistif sebanyak 58 kasus (Dinkes Provinsi Jateng, 2014). Oleh karena itu, peneliti tertarik untuk mengetahui Hubungan Kebiasaan makan dan Asap Rokok terhadap hasil pemeriksaan IVA di Kabupaten Pekalongan.

\section{METODE PENELITIAN}

Penelitian ini merupakan penelitian deskriptif korelatif dengan pendekatan cross sectional. Populasi penelitian ini adalah seluruh wanita usia subur di wilayah Kabupaten Pekalongan. Subyek penelitian ini seluruh wanita di wilayah Kabupaten Pekalongan yang melakukan pemeriksaan IVA di STIKES 
Muhammadiyah Pekajangan Pekalongan pada tanggal 6 Maret 2018 yang berjumlah 206 orang. Pada penelitian ini menggunakan alat pengumpulan data berupa kuesioner. Analisa data dalam penelitian ini menggunakan Uji Spearman Rank.

\section{HASIL DAN PEMBAHASAN}

Hasil penelitian Hubungan kebiasaan makan dan terpapar asap rokok dengan hasil pemeriksaan IVA di kabupaten Pekalongan yang yang dilakukan terhadap 206 responden pada tanggal bulan 6 Maret 2018 adalah sebagai berikut :

Tabel 1 Analisa Distribusi Responden Gambaran Kebiasaan Makan Pada Wanita Yang Melakukan Pemeriksaan IVA

\begin{tabular}{llll}
\hline Variabel & kategorik & Frekuensi & Prosentase (\%) \\
\hline Kebiasaan Makan & Tidak Sehat & 160 & 77,7 \\
& Sehat & 46 & 22,3 \\
\hline & Total & 206 & 100 \\
\hline
\end{tabular}

Dari Tabel 1 menunjukkan bahwa kurang dari sebagian besar wanita yang melakukan pemeriksaan IVA mempunyai kebiasan makan mengkonsumsi makanan berlemak dan berpengawet yaitu 160 orang $(77,7 \%)$

Tabel 2 Analisa Distribusi Responden Gambaran Asap Rokok Pada Wanita Yang Melakukan Pemeriksaan IVA

\begin{tabular}{llll}
\hline Variabel & kategorik & Frekuensi & Prosentase (\%) \\
\hline Asap Rokok & Terpapar & 79 & 38.3 \\
& Tidak Terpapar & 127 & 61.7 \\
\hline & Total & 206 & 100
\end{tabular}

Tabel 2 menunjukkan bahwa kurang dari separuh wanita yang melakukan pemeriksaan IVA terpapar asap rokok yaitu 79 orang (38.3\%)

Tabel 3 Analisa Distribusi Responden Gambaran Hasil Pemeriksaan IVA

\begin{tabular}{llll}
\hline Variabel & kategorik & Frekuensi & Prosentase (\%) \\
\hline $\begin{array}{l}\text { Hasil pemeiksaan } \\
\text { IVA }\end{array}$ & Positif & 10 & 4,9 \\
& Negatif & 196 & 95,1 \\
\hline & Total & 206 & 100 \\
\hline
\end{tabular}

Tabel 3 menunjukkan bahwa sebagian kecil wanita yang melakukan pemeriksaan IVA mendapatkan hasil pemeriksaan IVA positif sebanyak 10 orang $(4,9 \%)$

Tabel 4 Analisa Distribusi Hubungan Kebiasaan Makan Terhadap Hasil Pemeriksaan IVA

\begin{tabular}{|c|c|c|c|c|c|c|}
\hline & & \multicolumn{4}{|c|}{ Hasil Pemeriksaan IVA } & \multirow{3}{*}{ Nilai P } \\
\hline & & \multicolumn{2}{|c|}{ Positif } & \multicolumn{2}{|c|}{ Negatif } & \\
\hline & & $\mathrm{N}$ & $\%$ & $\mathrm{n}$ & $\%$ & \\
\hline \multirow{3}{*}{$\begin{array}{l}\text { Kebiasaan } \\
\text { Makan }\end{array}$} & Tidak & 9 & 5,6 & 151 & 94,4 & 0,340 \\
\hline & Sehat & 1 & 2,2 & 45 & 97,8 & \\
\hline & Total & 10 & 4,9 & 196 & 95,1 & \\
\hline
\end{tabular}


Dari Tabel 4 didapatkan hasil bahwa tidak terdapat hubungan antara kebiasaan makan dengan hasil pemeriksaan IVA karena nilai $\mathrm{p}>0,05$.

Tabel 5 Analisa Distribusi Hubungan Asap Rokok Terhadap Hasil Pemeriksaan IVA

\begin{tabular}{|c|c|c|c|c|c|c|}
\hline & & \multicolumn{4}{|c|}{ Hasil Pemeriksaan IVA } & \multirow{3}{*}{ Nilai $P$} \\
\hline & & \multicolumn{2}{|c|}{ Positif } & \multicolumn{2}{|c|}{ Negatif } & \\
\hline & & $\mathrm{N}$ & $\%$ & $\mathrm{~N}$ & $\%$ & \\
\hline \multirow{3}{*}{$\begin{array}{l}\text { Asap } \\
\text { Rokok }\end{array}$} & Terpapar & 6 & 7,6 & 73 & 92,4 & 0,150 \\
\hline & $\begin{array}{l}\text { Tidak } \\
\text { Terpapar }\end{array}$ & 4 & 3,1 & 123 & 96,9 & \\
\hline & Total & 10 & 4,9 & 196 & 95,1 & \\
\hline
\end{tabular}

Tabel 5 didapatkan hasil bahwa tidak terdapat hubungan antara asap rokok ndengan hasil pemeriksaan IVA karena nilai p>0,05.

\section{Kebiasaan Makan Pada Wanita Yang Melakukan Pemeriksaan}

Hasil analisa univariat variabel kebiasaan makan didapatkan sebagian besar wanita yang melakukan pemeriksaan IVA mempunyai kebiasan makan mengkonsumsi makanan berlemak dan berpengawet yaitu 160 orang $(77,7 \%)$. Hal ini merupakan kebiasaan yang tidak sehat dalam pemilihan jenis makanan yang dikonsumsi, sehingga dapat mengakibatkan resiko berbagai penyakit degeneratif seperti penyakit jantung koroner, dislipidemia, diabetes mellitus, obesitas dan stroke. Penelitian yang dilakukan Kandau (2009) mengenai kebiasaan makanan berlemak di daerah minahasa, diperoleh hasil bahwa masyarakat yang memiliki kebiasaan makanan berlemak, 61\% menderita hipertensi, 62,5\% menderita obesitas dan $53 \%$ menderita diabetes mellitus.

Penelitian ini diperoleh data bahwa dari 46 orang yang melakukan prinsip hidup sehat hanya ada 1 orang yang didapatkan hasil pemeriksaan IVA positif. Kebiasaan konsumsi sayur dan buah sebagai anti-oksidan dan berkhasiat mencegah kanker misalnya alpokat, brokoli, kol,wortel, jeruk, anggur, bawang, bayam, tomat. Defisiensi asam folat, vitamin E, beta karoten/retinol beresiko untuk meningkatkan penyakit kanker serviks.Vitamin $\mathrm{E}$, vitamin $\mathrm{C}$ dan beta karoten memiliki khasiat antioksidan yang kuat.Antioksidan dapat melindungi DNA/RNA terhadap pengaruh buruk radikal bebas yang terbentuk akibat oksidasi karsinogen bahan kimia.Vitamin E banyak terdapat dalam minyak nabati (kedelai, jagung, biji-bijian dan kacang-kacangan).Vitamin $\mathrm{C}$ banyak terdapat dalam sayursayuran dan buah-buahan (Pangesti, Cokroaminoto, dan Nurlaila, 2012).

\section{Terpapar Asap Rokok Pada Wanita Yang Melakukan Pemeriksaan}

Hasil penelitian ini diperoleh data bahwa wanita yang datang untuk pemeriksaan IVA sebesar 79 orang (38.3\%) terpapar asap rokok. Dalam 1 batang rokok mengandung 4000 zat kimia yang berbahaya bagi kesehatan, 200 diantaranya merupakan bahan beracun yang terdiri dari gas $85 \%$ dan partikel yakni nikotin, gas karbon monosida, nitrogen oksida, hidrogen sianida, amoniak, akrolein yang bahan-bahan tersebut dapat menyebabkan kanker bagi tubuh 
(Ahmad, 2010). Resiko perokok pasif (orang disekitar perokok yang terhisap asap rokok) tidak kalah besarnya dari perokok untuk menderita penyakit (Djauzi, 2009). Dampak asap rokok bagi kesehatan yakni menyebabkan kerontokan rambut, penyakit jantung, stroke, kanker paru, kanker payudara, kanker payudara, kanker serviks (Tumigolung, Wungouw, dan Onibala, 2013)

\section{Hasil pemeriksaan IVA}

Hasil penelitian ini diperoleh data bahwa 10 responden $(4,9 \%)$ terdeteksi hasil pemeriksaan IVA positif. Metode Inspeksi Visual Asetat (IVA) merupakan upaya yang dilakukan wanita dalam rangka skrening terhadap kanker serviks yang memiliki keunggulan diantaranya metode yang sederhana menggunakan asam asetat 3-5\% dan memiliki keakuratan 90\% (Widyastuti, Rahmawati dan Purnamaningrum, 2009). Hasil penelitian yang dilakukan Wiyono, Iskandar dan Suprijono (2008) memperoleh hasil bahwa pemeriksaan IVA memiliki sensitifitas dan spesifisitas yang tinggi untuk digunakan sebagai metode penapisan lesi pra kanker atau keganasan serviks uteri, namun hasil pemeriksaan IVA positif membutuhkan pemeriksaan yang lebih lanjut untuk konfirmasi diagnostik.

Sensitivitas pemeriksaan IVA sampai $96 \%$ dan spesifisitas $97 \%$ untuk program yang dilaksanakan oleh tenaga medis yang terlatih, sedangkan pemeriksaan pap smear memerlukan waktu dan biaya besar serta memiliki spesitivitas $51 \%$ dan spesifisitas $98 \%$. Hal ini menunjukkan bahwa IVA memiliki spesiditas yang hampir sama dengan sitologi serviks (pap smear) sehingga dapat menjadi metode skrining yang efektif pada negara berkembang seperti di Indonesia (Saraswati, 2009).

\section{Hubungan Kebiasaan Makan Terhadap Hasil Pemeriksaan IVA}

Hasil penelitian ini diperoleh bahwa kebiasaan makan tidak berubungan dengan hasil pemeriksaan IVA dengan nilai p 0,340.Kebiasaan makan berlemak memicu perubahan aktivitas sistem enzim sitokrom oksidase P-448/450 pada metabolisme zat-zat kimia karsinogen dan obat-obatan.Penelitian yang dilakukan peneliti dari Amerika dan Canada menemukan bahwa kandungan asam linoleat asam lemak tak jenuh jamak yang banyak terdapat dalam minyak sayur meningkatkan resiko tumor payudara.Minyak tak jenuh jamak dalam kulit segera dioksidasi oleh radiasi ultra violet dari matahari dan membentuk radikal bebas yang merugikan.Hal ini dapat merusak DNA sel dan menyebabkan kanker kulit (Tunimah, 2009).

Hasil penelitian ini tidak sesuai dengan pendapat Syifanoe dalam Pangesti, Cokroaminoto, dan Nurlaila (2012) yang menjelaskan bahwa munculnya sel kanker berkaitan erat dengan pola makan seseorang. Wanita yang banyak mengkonsumsi lemak akan lebih beresiko terkena kanker endometrium, hal ini disebabkan dalam lemak mengandung hormon estrogen yang mudah berubah sifat menjadi kanker. Dalam penelitian ini hasil menunjukkan tidak ada hubungan antara kebiasaan makan dengan hasil pemeriksaan IVA kemungkinan dikarenakan timbulnya kanker leher rahim memerlukan waktu beberapa tahun sejak sel-sel serviks mengalami perubahan.Sel-sel serviks abnormal yang bukan merupakansel kanker namun dapat berkembang menjadi kanker disebut dengan cervikal intraepithelial neoplasia (CIN).Perkembangan kanker serviks meliputi displasia ringan (5 tahun), displasia sedang (3 tahun), displasia berat (1 tahun) sampai menjadi 
kanker stadium 0.Oleh sebab itu pencegahan sedini mungkin kanker serviks sangatlah penting.

\section{Hubungan Asap Rokok Terhadap Hasil Pemeriksaan IVA}

Hasil penelitian ini menujukkan nilai p sebesar 0,140 yang berarti tidak terdapat hubungan antara paparan asap rokok dengan hasil pemeriksaan IVA. Hasil penelitian ini tidak sejalan dengan penelitian yang dilakukan Sulistiowati dan Sirait (2014) yang menyebutkan bahwa wanita yang merokok memiliki resiko 2 kali lebih besar untuk dapat terkena kanker serviks dibandingkan dengan wanita yang tidak merokok Konsentrasi nikotinwanita perokok pada getah serviks 56 kali lebih tinggi dibandingkan di dalam serum, yang akan menurunkan status imun lokal sehingga bersifatkokarsinogen dari infeksi virus.

Penelitian ini diperoleh data bahwa $7,6 \%$ wanita yang melakukan pemeriksaan IVA terpapar asap rokok (perokok pasif) yang memiliki resiko sama besarnya dengan perokok aktif. Wanita perokok atau terpapar asap rokok memiliki resiko lendir serviks mengandung nikotin dan zat-zat lainnya yang ada didalam rokok. Zat-zat tersebut akan menurunkan daya tahan serviks disamping merupakan ko-karsinogen infeksi virus (Saraswati, 2009).

Hasil penelitian ini tidak sejalan dengan penelitian yang dilakukan Dewi, Sawitri dan Adiputra (2013) yang memperoleh hasil bahwa paparan asap rokok meningkatkan risiko terjadinya lesi pra kanker leher rahim sebesar 4 kali dibandingkan tanpa paparan asap rokok. Dalam penelitian ini responden yang mengalami paparan asap rokok didapat di rumah atau di tempat kerja dimana paparan asap rokok terjadi pada 79 responden dengan hasil pemeriksaan IVA positif pada 6 responden

\section{SIMPULAN DAN SARAN}

\section{Simpulan}

Sebagian besar wanita yang melakukan pemeriksaan IVA mempunyai kebiasan makan mengkonsumsi makanan berlemak dan berpengawet yaitu 160 orang $(77,7 \%)$, Kurang dari separuh wanita yang melakukan pemeriksaan IVA terpapar asap rokok yaitu 79 orang $(38.3 \%)$, Sebagian kecil wanita yang melakukan pemeriksaan IVA mendapatkan hasil pemeriksaan IVA positif sebanyak 10 orang (4,9\%), Tidak terdapat hubungan antara kebiasaan makan dengan hasil pemeriksaan IVA karena nilai $\mathrm{p}>0,05$., Tidak terdapat hubungan antara asap rokok dengan hasil pemeriksaan IVA karena nilai $\mathrm{p}>0,05$

\section{Saran}

Bagi tenaga kesehatan khususnya bidan dapat memberikan informasi mengenai faktor-faktor yang dapat meningkatkan resiko kanker serviks pada wanita reproduksi, sehingga muncul kesadaran dari wanita untuk menghindari faktor pemicu dari kanker serviks. 


\section{DAFTAR PUSTAKA}

Ahmad R. R. 2010. Merokok Haram. Jakarta: PT.Gramedia.

Aris W. 2015.Kajian Deteksi Dini Lesi Prakanker Leher Rahim dengan Metode IVA. Kabupaten Karanganyar.

Dewi, IGAAN., Sawitri AAS., dan Adiputra N. 2013. Paparan asap rokok dan hiegiene diri merupakan faktor risiko lesi prakanker leher rahim di Kota Denpasar. Public Health preventive medicine Archive, 1(1), 84-91

Diananda, 2009. Panduan lengkap mengenal kanker.Yogyakarta.Mirza Medika Pustaka

Djauzi, S. 2009. Raih Kembali Kesehatan. Jakarta: Kompas

Handayani Lestari, Suharmiati, Atika ayuningtyas. 2012.Menaklukkan kanker serviks dan kanker payudara dengan 3 terapi alami. Agro : Media Pustaka. Jakarta

Kandau, GD. 2009. Kebiasaan Makan makanan Etnik Minahasa di Provinsi Sulawesi Utara.

Kemenkes RI. 2015. Penanggulangan kanker Payudara dan kanker leher rahim.Kemenkes. Jakarta.

Kurniasari I. 2012. Kesehatan Reproduksi untuk mahasiswa kebidanan dan keperawatan. Salemba Medika. Jakarta.

Lestari, N.D. 2016. Faktor-Faktor yang berhubungan dengan kejadian IVA positif pada wanita berusia 30-50 tahun di Kabupaten Sukoharjo.Skripsi. Jurusan Ilmu Kesehatan Masyarakat Fakultas Ilmu Olahraga. Universitas Negeri Semarang.

Novya Dewi GA, Sawitri A.A.S, Adiputra. 2012. Paparan Asap rokok dan Higiene diri merupakan factor risiko lesi prakanker leher rahim di kota denpasar.Jurnla Public Health and Preventive Medicine Archive, volume 1 nomor 1 Juli 2013.

Pangesti, NA., Cokroaminoto., Nurlaila. 2012. Gambaran karakteristik Wanita Usia Subur (WUS) yang melakukan pemeriksaan Inspeksi Visual Asam Asetat (IVA) di puskesmas Karanganyar. Jurnal Ilmiah Kesehatan keperawatan. 8(2), 81-94

Ranggiasanka,A, 2010. Waspada Kanker Pada Pria dan Wanita. Yogyakarta Hanggar Kreator.

Rasjidi, I. 2009. Deteksi dini Pencegahan kanker padawanita. Jakarta : CV Sagung Seto.

Saraswati, LK. 2009. Pengaruh Promosi Kesehatan Terhadap Pengetahuan Tentang Kanker Serviks dan Partisipasi Wanita dalam Deteksi Dini Kanker Serviks (DI Mojosongo RW 22 Surakarta).Tesis. Universitas Sebelas Maret: Surakarta

Sulistiowati, E dan Sirait, AM.2014. Pengetahuan Tentang Faktor Risiko, Perilaku dan Deteksi DiniKanker Serviks dengan Inspeksi Visual Asam Asetat (IVA)Pada Wanita Di Kecamatan Bogor Tengah, Kota Bogor.Buletin Penelitian Kesehatan, 42 (3), 193-202 
Tumigolung, HCS., Wungouw, H., dan Onibala, F. 2013. Pengaruh Pendidikan Kesehatan Terhadap Tingkat Pengetahuan Siswa Tentang Bahaya Merokok Di SMA Negeri 1 Manado.Jurnal Keperawatan. 1(1) 1-7

Tuminah, S. 2009. Efek Asam Lemak jenuh dan asam lemak tak jenuh "Trans" terhadap kesehatan.Media penelitian dan pengembangan kesehatan. 19 (2) S13-S-20

Widyastuti, Y., Rahmawati, A., \& Purnamaningrum, Y.A. (2009).Kesehatan Reproduksi. Yogyakarta : Fitramaya

Wiyono, S., Iskandar, TM., Suprijono. 2008. Inspeksi Visual Asetat (IVA) untuk deteksi dini Lesi Prakanker Serviks. Journal media medika Indonesia, 43(3) 116-121 